\title{
INDEPENDENCE OF CENTRAL BANK AS A BASIS FOR INSTITUTIONAL POLITICS OF MONETARY POLICY
}

\author{
by Ireneusz Kraś

\section{INTRODUCTION}

The course of economic processes of economy is regulated by its products and production factors in which supply and demand are equalized. The most important role is given to money as a measurement of value (ensuring valuation), means of payment (allowing the settling the payments) as well as a means of hoarding (allowing savings) ${ }^{1}$.

Primarily the market economy is a monetary economy. Money is used for buying and selling, for granting loans, accumulating savings. Every functional entity of the market such as enterprises, households are taking part in these processes. An important role of these processes is taken by the purchasing power of money, which has an effect on those participating in economy and social life. If the value of the money is constant it brings safety in life not only from the economic but also the social point of view. We can not agree more than to say that stable currency is of great social value. The central bank takes a major role to a guard keeping the currency

\footnotetext{
${ }^{1}$ G. Wójtowicz, Bankowość centralna od A do Z. Bank centralny $w$ gospodarce rynkowej, "Bank i Kredyt" 2006, No. 1, p. 3.
} 
at a stable level ${ }^{2}$. Proper functioning of the central bank is strictly connected with its independence. It allows the monetary policy to be conducted properly in a country.

\section{THE CONCEPT AND CLASSIFICATION OF THE INDEPENDENCE OF THE CENTRAL BANK}

The discussion on the independence of the central bank is one of the most dynamic research areas at the moment. It is strictly connected with the relation of the independence of the central bank and keeping inflation at a low level.

The proposal of the central bank appeared in relation to the contestation of the ability of increasing employment by means of expansion of monetary policy for the longer period of time. The dangerous side of this policy is higher inflation which has a negative effect on the economy. Before elections political parties tend to "loosen" the monetary policy. The aim of using such a tactic is to gain more votes ${ }^{3}$.

Precise clarification of the independence of the central bank is not an easy task and it is difficult to describe using one definition. R. Huterski clearly defines the independence of the central bank as depriving it of executive power to make important decisions, and at the same time depriving it of legislature power to interfere in the policy of the bank ${ }^{4}$.

The independence of the central bank is connected with the relation of the central bank and government. We may compare it with the relationship between judiciary and executive, which is based on the tracheotomy of the power of Monteskiusz ${ }^{5}$. Judiciary in the court is modelled on the law

\footnotetext{
2 I. Kraś, Niezależność polityczna Europejskiego Banku Centralnego, [in:] Res Politicae, ed. H. Ćwięk, Częstochowa 2009, p. 270.

3 W. Baka, Bankowość centralna. Funkcje, metody, organizacja, Warszawa 2001, p. 83.

4 R. Huterski, Niezależność banku centralnego, Toruń 2000, p. 22.

5 Monteskiusz formulated the rule of tracheotomy of the government into: legislature, executive, judiciary. This division of remit and control concerns only the relationship between the parliament, the government and the court. He stated that the quality of the country depends on the freedom of its citizen, which is promoted by the restrict-
} 
created by the legislature. In order to make any changes the law has to be changed.

Recently the central bank has been considered as a fourth state power due to its rising independence. It is connected with the fact that the central banks took over a part of the responsibilities of economic policy that over past years belonged to the government. What is more they received an assurance of independence from the government. The vital part of economic policy which is a monetary policy has become the responsibility of the central bank.

The need for independence of the central bank is connected with the function of the money in a free market society. It means that, the purchasing power of money depends on common acceptance of a society, not the internal value of the item. It turns out that the purchasing power of money is strictly connected with setting up the institutions, which are responsible for running the monetary policy, and the central bank is one of these $\mathrm{e}^{6}$. The independence of the central bank is a vital aspect when considering the conduct of this policy.

According to M. Sobol these are the basic elements defining the independence of the central bank:

- identification of lawful purposes of the central bank,

- competence in establishing these purposes

- independence in implementing these targets

- general independence from politics

- ban on financing of budget deficit

- detailed rules of announcing, calling off the current term of office of the central bank,

- no restrictions on contact with the surrounding ${ }^{7}$

We may encounter various divisions of the independence of the central bank. The most popular division of the independence of the central bank:

ing of the power of government, and especially its division. Formulating the system of tracheotomy was supposed to give institutional guarantee for the freedom of an individual.

6 W. Baka, Bankowość centralna. Funkcje..., op.cit., p. 83.

7 M. Sobol, Polityka pieniężna Narodowego Banku Polskiego w drodze do euro, Warszawa 2008, pp. 86-87. 
- personal independence

- financial independence

- functional independence

- institutional independence

Personal independence is associated with calling up and calling off the authorities. It also makes sure that their term is protected and continuous during this time. It is very important that government has minimal influence on the procedure of the banks for appointing authorities. In such a case the influence of the executive on the monetary policy is being reduced.

Financial independence also plays an important role. It is linked with the determination of the principles, governing the creation and distribution of the central bank funds to ensure its independent operation, which will prevent any pressure on its decisions. Financial independence also implies prohibition on financing budget deficit and a ban on financing bank losses from the budget.

Functional independence, which is related to the conduct of monetary policy, is the freedom a central bank should have in its formulation and implementation. This aspect of independence should be seen in terms of independence of the choice of objectives and instruments of monetary policy. Independence of the central bank aims as its power to choose the main objective. The main objective of the central bank should be specified in the statute. This reduces the risk of legal status to submit the goal of price stability objectives which can be less relevant for monetary policy. The independence of the choice of instruments is what powers the central bank in relation with the free use of instruments that can help achieve the goals. The use of monetary policy instruments in the case of the independence of the central bank does not require the consent of the government ${ }^{8}$. In addition, qualifying factors of financial independence are a constitutional definition of the mission of the central bank and the ability to conduct exchange rate policy of the sovereign'.

8 M. Kasprzyk, Problem niezależności banku centralnego, [in:] Bank centralny w Polsce, ed. J. Świderska, Warszawa 2010, pp. 59-60.

9 M. Sobol, Polityka ..., op.cit., p. 87. 
Institutional independence defined as the location of the central bank in the system of state bodies and the manner of appointment and dismissal of the bank authorities (being elected, during the term of occupancy) ${ }^{10}$. A particularly important form of institutional independence is to give the central bank legal personality ${ }^{11}$.

European Monetary Institute (EMI) has developed a list of elements of the independence of the central bank. This list shall form the previously described aspects of independence. EMI has made certain assumptions. One of them is that the independence of the central bank is not an issue which can be defined as an arithmetic formula. The independence of the central banks should be assessed individually in connection with the various institutional arrangements in individual countries. Another assumption is that the characteristics of the independence of the central bank should be considered from the perspective of the use of its powers and performance of the duties and tasks assigned to it by legislation ${ }^{12}$.

Another classification for the one presented above is by V. Grilliego, D. Masciandaro and G. Tabelliniego. It distinguishes economic and political independence of the central bank. Economic independence is the ability to control the amount of the central bank credit granted to the government and to determine interest rates, the control of the instruments of monetary policy, setting interest rates and supervision of the banking sector.

Political independence while showing us the extent to which the central banks may define their goals without interference from the government. The notion of political independence is wider than independence in choosing targets, for it takes into account not only the impact of political forces in determining monetary policy purposes, but also their subsequent impact on the achievement of these objectives ${ }^{13}$. The proposal of political

\footnotetext{
10 W. Baka, Bankowość centralna. Funkcje..., op.cit., p. 86.

11 Vide Art. 106, paragraph 2 the Treaty of European Union, eur-lex.europa.eu, art. 9.1 Statutu ESBC/EBC, http://www.ecb.int/ecb/legal/pdf/pl_statute_from_c_11520080 509p102010328.pdf [14.07.2011]

12 Progress Towards Convergence 1996, European Monetary Institute, November 1996, p. 99 et al., http://www.ecb.int/pub/pdf/conrep/cr1996en.pdf

13 R. Huterski, Niezależność..., op.cit., p. 26.
} 
independence of the central bank was included in Article 108 of the Treaty on European Union and Article 7 of the Statute. According to these articles neither the European Central Bank nor a national central bank, or any members of the governing bodies should seek or take instructions or accept orders from Community institutions or bodies, from national governments or from any other bodies. Community institutions and bodies and the governments of the Member States are assumed to respect this principle and not seek to influence the decision-making bodies of the ECB or national central banks in carrying out their duties ${ }^{14}$.

In the objective sense the independence of the central bank can be seen in three aspects:

- as full independence, relating to the definition of objectives and their instantiation, as well as methods and tools for implementation of monetary policy by the central bank,

- as operational independence associated with the privileges of an independent central bank to concrete objectives set out in legal acts of higher order to which the constitution and law is included. The scope also includes the operational independence of the powers as to the selection and application of methods and tools of monetary policy of the central bank,

- as an independent implementation, involving the permission of the central bank, only for self-determining and applying the tools of monetary policy implementation methods ${ }^{15}$.

The process of adapting to European Union countries into the European UG and the (Economic and Monetary Union) forces a change of status of the central banks, which were previously subordinate to the government. The concept of institutional independence, personal, functional and financial is considered separately for each country. It represents a degree

\footnotetext{
14 Art. 7, Protokół w sprawie Statutu Europejskiego Systemu Banków Centralnych i Europejskiego Banku Centralnego, http://www.ecb.int/ecb/legal/pdf/pl_statute_2.pdf [18.07.2011]

15 W. Baka, Geneza, funkcje i niezależność banku centralnego, [in:] Studia z bankowości centralnej i polityki pieniężnej, ed. W. Przybylska-Kapuścińska, Warszawa 2009, p. 95.
} 
of convergence of legislation of countries with derogation ${ }^{16}$. This adjustment is to take place under the provisions of the Maastricht Treaty. The independence of the central banks is often considered the sixth condition for accession to the European EMU17.

\section{MODELS OF CENTRAL BANKING IN EUROPE}

In the post-war period we were dealing with two models of central banking in Europe: a model of Franco-British and German model ${ }^{18}$. In the Franco-British model, the central bank is interested in the achievement of objectives which include: price stability, high economic growth, stabilization of the business cycle, low unemployment, maintenance of high employment rates, financial stability. In this model, price stability is one of the few goals that implement the central bank. This model was characteristic of the bank for most countries in the world in the period after World War II and reflects the historical position of the two former colonial powers in international relations.

After World War II, inflation was not at the centre of thinking about the economy. Economic policies of the government in most countries had been supported by the central banks, they were giving the loans to the companies and were maintaining interest rates at a level sufficient for rapid economic development The government defined the policies of the bank, leaving in its discretion, implementation tasks. Such a dependence of the central bank's monetary policy supports the government's economic policy, regardless of the consequences of inflation. There can be two independent centres conducting politics, the first - general economic (govern-

16 Derogation is a concept, which relates to the members of European Union, which for a certain time not able to fulfil the criteria of convergence, which are essential for the recognition of a mutual currency.

17 E. Latoszek, Etapy integracji walutowej w Unii Europejskiej, "Bank i Kredyt" 2008, No. 3, p. 22.

18 Sytuacja ta współgrała z pozycją międzynarodową zróżnicowanych aktorów państwowych polityki europejskiej. See more: M. Dobroczyński Ekonomiczne Mocarstwa Unii Europejskiej, Toruń 2003. 
ment), the second - the monetary (the central bank) ${ }^{19}$. Such a connection of government with the central bank is supported by the fact that there can be no authority for such a big democratic power not subjected to verification. It can be concluded that in this model the central bank was dependant on political authorities. It was connected with the fact that all decisions related to monetary policy were made by the politicians from the government (Minister of Finance). In this model, we are dealing with the influence of politics on the functioning of the central bank.

Loosening of monetary policy and allow inflation in the short term actually causes economic growth and lower unemployment. However, the question arises what will such a policy bring in the long run? Here there is a serious problem because in the long run it will cause a slowdown in the economy and leads straight to the crisis.

The effects of such activities were seen in the 70's when the world was in a deep economic crisis with inflation at a high level. This situation has changed thanks to the views of Milton Friedman. He believed that in the long run inflation is a monetary phenomenon which means that it is caused by an increase in the quantity of money in circulation. Increase in cash in the long run cannot ensure faster economic growth, but rising prices or inflation.

The second model of banking - German - based on completely different, more pragmatic foundations. The basis of its functioning is political independence. Monetary policy decisions are taken by the bank itself without the interference of political authorities. Central bank is independent from the government and it runs without their interference. The primary purpose of this bank is to care about price stability. A bank, which is freed from political pressures may be in the longer term, base their decisions on an objective assessment of the situation and realistic economic forecasts. In addition, the higher the independence of the central banks the lower the prices, growth and improved macroeconomic performance. This group includes the Polish National Bank.

19 J. Pietrucha, Autonomia banku centralnego z punktu widzenia ekonomicznej teorii polityki, “Bank i Kredyt” 1994, No. 12, p. 28. 


\section{DETERMINANTS \\ OF THE INDEPENDENCE OF CENTRAL BANK}

The degree of independence of the central banks varies in different countries. However, generally there is a tendency to increase it. It is primarily affected by the provisions of the Maastricht Treaty relating to the desire to harmonize the activities of the national central banks with the Statute of the European System of Central Banks (ESCB) ${ }^{20}$.

In literature there are two aspects of argument in favour of the independence of the central bank. The first aspect of argument is based on an analysis of cause and effect. It shows that the central bank is more resistant to the effects of politics, especially in the periods prior to elections. Central bank without political pressure is able to operate in the longer term, and it bases its decisions on an objective assessment of the situation and realistic forecasts. In this way, it can protect the stability of the currency, therefore it contributes to stabilization of the economic and political situation $^{21}$.

Political instability affects the independence of the central bank. Political pressures are associated with the fact that politicians are usually impatient and seek immediate action to obtain specific results. Governments wishing to increase their popularity and chances for re-election will try to decrease interest rates, thereby increasing the money supply ${ }^{22}$. The result of such actions in the short term will decrease unemployment however it will increase inflation. The conduct of monetary policy is best for the long term due to the delay which reveals its impact on inflation. Resistance of the central bank towards political pressure leads to public confidence, thereby the effectiveness of the monetary policy is increas-

20 B. Pietrak, Niezależność Narodowego Banku Polskiego jako warunek realizacji jego podstawowych funkcji w gospodarce rynkowej, [in:] Bankowość, eds. J. Głuchowski, J. Szambelańczyk, Poznań 1999, p. 96.

21 W. Baka, Bankowość europejska, Warszawa 2005, p. 64.

22 The supply is the amount of money circulating within the economy. It is measured by means of hoard which has different levels of rotation. 
ing ${ }^{23}$. The occupancy of the central bank authorities longer than the period between the elections favours the policy of isolation from electoral cycle ${ }^{24}$.

In the event of losing power by the ruling political parties, the likelihood of transmission of monetary policy for non-political institution like the central bank will be increased. This situation will lead to a reduction of political resources when the opposition parties take power. On the other hand if the probability of regime change is higher, they may seek to strengthen control over the central bank and take over control of it. In this case, the burden of the cost of inflation will fall in time in which the opposition will be ruling. In the first case, the greater political instability leads to a more independent central bank. This is possible if the political scene is sufficiently separated. The second case leads to a greater dependence of the central bank on governing 25 .

The independence of the central bank is also connected with the supervision of financial institutions. This case allows two solutions:

- central bank being responsible for monetary policy and financial supervision,

- central bank being responsible only for monetary policy and financial supervision appointed to a suitable institution.

The second solution which is a separation from the conduct of monetary policy increases the independence of financial supervision of the central bank. In the first solution the central bank may be tempted to submit the supervision over the stability of prices. Separation of these functions makes it possible to increase the effectiveness of monetary policy practised by the central bank. An important argument for the separation of monetary policy and financial supervision is a bad social image associated with insolvencies or rescue operations. However, in the event of bankruptcy of the smaller banks the stability of the central bank is not affected. In the case of bankruptcy of a major bank responsibility

\footnotetext{
${ }^{23}$ M. Kasprzyk, Problem niezależności banku centralnego, [in:] Bank centralny w Polsce, ed. J. Świderska, Warszawa 2010, p. 65.

24 R. Huterski, Niezależność..., op.cit., p. 138.

25 Por. A. Jabłońska, Cykl koniunkturalny, [in:] Podstawy ekonomii, ed. R. Milewski, Warszawa 2000, p. 519; R. Huterski, Niezależność..., op.cit., pp. 84-85.
} 
for this will be transferred to the central bank, because it did not take financial control. It will be accused of bad monetary policy as a last resort borrower ${ }^{26}$.

The most important fact of the central bank not taking control is the fact that the central banks which do not take financial supervision have lower inflation. This relationship is validated by the results of statistics.

The correlation between the degree of independence of the central bank and stabilization of price levels and overall results achieved in the economy (economic growth, balance of trade, modernisation of the economy) is the second aspect of argument in favour of the independence of the central bank. The correlation between these variables is high and indicates that, with the higher independence of the central bank, there is a lower rate of price growth and macroeconomic performance is improved ${ }^{27}$.

There are arguments for and against in the discussion of independence of the central bank. Supports of the independence of the central bank generally refer to the following arguments:

- establishment of an independent central bank as a proxy to fight inflation could be a mean for the government to meet its commitments to disinflation,

- independence of the central bank gives greater assurance that the government will not use monetary policy, which is part of state economic policy for political purposes,

- in order not to give the monetization of the budget deficit, the government may be forced to greater fiscal discipline,

- independence of the central bank increases its credibility and at the same time inflation expectations decreases;

- transferring the right to make decisions to the central bank can shorten the time in which they will be achieved. ${ }^{28}$

\footnotetext{
26 One of the functions of the central bank is "the borrower of the last resort" depending on stabilization of financial market. When performing this function the central bank is supporting other banks by granting them loans. It also helps other financial institutions, because the financial panic can put in danger the whole financial system of a country.

27 W. Baka, Bankowość centralna..., op.cit., p. 84.

28 W.L. Jaworski, System bankowy w Polsce, [in:] Współczesny bank, ed. W.L. Jaworski, Warszawa 1999, p. 72.
} 
The remaining arguments related to the independence of the central bank quoted in the literature include:

- reducing the problem of dynamic inconsistency and inflationary bias,

- increasing the credibility of politics,

- reducing inflation volatility,

- limiting the interchange ability of inflation - economic growth in the long run,

- allowing the central bank to focus on one goal29.

Strong arguments in favour of the independence of the central bank were not supported by appropriate mechanisms for appointing authorities of the central bank. They would ensure that the credibility of the future is protected by fuelling the development of a strong financial sector as opposed to inflation, investing in the reputation of the central bank and longer term authority ${ }^{30}$.

In presenting the arguments for, there should also be put forward the arguments against the independence of the central bank. These include:

- Far-reaching powers of the central bank limit the possibility of flexible economic politics responding to any unforeseen 'economic shocks';

- the independence of the central bank makes it difficult to find the optimal solution to reduce unemployment;

- the independence of the central bank leads to an artificial separation of fiscal and monetary policy, and yet the effectiveness of monetary policy not only depends on the actions of the central bank, but also on the overall macroeconomic policy;

- independence of the central bank would make sense if it were decided people who are strictly not connected with it; Meanwhile, in modern countries the central bank is part of the political and economic system and, therefore, is neither apolitical expert committee, nor impartial observer ${ }^{31}$;

29 M. Kowalak, Instytucjonalne podstawy polityki pieniężnej, [in:] Współczesna polityka pieniężna, ed. W. Przybylska-Kapuścińska, Warszawa 2008, p. 210

${ }^{30}$ R. Huterski, Niezależność..., op.cit., p. 138.

31 J. Piertucha, Autonomia banku centralnego..., op.cit., p. 28. 
- from societies point of view, excessive independence of the central bank is a sub-optimal;

- there is a deficit of democracy.

\section{DEMOCRATIC ACCOUNTABILITY OF CENTRAL BANK}

Regardless of the legal solutions in the relationship between the government and the central bank there is a continuous search for appropriate relationships between them. The government, which has constitutional authority to conduct short-term policies generally should consider having the central bank in the long-term, even if it is limited in its action. It is not easy to clarify these relationships. On the one hand, we have a democratically appointed government which cannot be restricted. On the other hand, they should be aware of other voters. The independence of the central bank as a body responsible for monetary policy is consistent with their expectations, which include the prevention of inflation and ensuring the highest possible employment level as well as economic growth. The central bank cannot deal only with economic policy, but may be affected to an extent to which it is connected with the stability of money ${ }^{32}$.

Central bank and other banks are special public institutions of social trust. Therefore it should be responsible for its actions. It is desirable if there is a mechanism of public control of the central bank which is responsible for monetary policy. It is demanded due to the fact that such independent central banks will practise monetary policy incompatible with the preferences of society.

The current institutional reforms gave the central bank the ability to conduct independent policy free from political pressures. The authorities who are not elected in the democratic elections are responsible for monetary policy. Transferring economic power can mean a deficit in democracy. In this case, the central bank sets the target of their own monetary policy. However, if this target is not achieved, the bank is not subjected to liability.

32 H. Gronkiweicz-Waltz, Bank centralny od gospodarki planowanej do rynkowej. Zagadnienia administracyjnoprawne, Warszawa 1992, pp. 37-38. 
The problem of deficit in democracy became the basis for the creation of the concept of democratic accountability. There can be three dimensions of democratic accountability:

- responsibility of the authorities,

- institutional responsibility,

- time responsibility ${ }^{33}$.

Implementation of the responsibility of the authorities by the central bank depends on fulfilling the set objectives. The main and only purpose of the central bank is to keep stable price levels. From the democratic accountability point of view, it is important that this is a very clear goal, which the bank is obliged to follow. Greater number of goals will be associated with and will promote the interchange ability of discretionary monetary policy. The responsibility of the authorities describes what the central bank is responsible for.

Another aspect of democratic accountability is connected with institutional responsibility. And it answers the question who the central bank depends on. This dimension concerns society, which has the democratic right to assess the central bank. The monetary authorities are not directly responsible to society, but to the representatives elected in democratic elections. These include the executive and legislative ${ }^{34}$.

The last dimension of democratic accountability concerns time delays associated with monetary policy. The assessment of the central bank monetary policy by society is possible after some time. Usually it takes several months. Sometimes it may appear that people in power at the central bank do not perform their duties, and therefore they cannot be held responsible for the results of their decisions ${ }^{35}$.

Central banks by being significantly independent are limiting their democratic accountability. It raises the problem among the ruling party of how to deal with this situation. Most countries with independent central banks are based on the reputation of their authorities. This situation cannot be afforded by developing countries where it is not possible to select

33 M. Kasprzyk, Problem..., op.cit., p. 66.

34 Cf. M. Kowalak, Instytucjonalne..., op.cit., p. 241; J. Mackiewicz-Łyziak, Wiarygodność banku centralnego, Warszawa 2010, p. 8

35 Ibidem, p. 242. 
qualified executives of the bank or monetary authority operates in difficult political environments. In the absence of explicit control mechanisms, the democratic accountability of the central bank may be maintained with the possibility of revocation. In this case, the government only withdraws its democratic power over monetary policy, renouncing it. In Poland such a way to preserve democratic accountability by the monetary authorities is impossible, because the independence of the central bank is guaranteed by the constitution ${ }^{36}$. The situation is somewhat different in the United States, where a level of uncertainty associated with independence is upheld. Activities that have been described above are only possible in countries with high political stability. Then they can keep the threat of renouncing of independence with little likelihood of its withdrawal. This practice definitely should not be used in countries with low political stability ${ }^{37}$.

A very important way used to restrict the independence of the central bank is announcing variable authorities. This procedure may reflect different impacts on economy. The authorities appointed in 1994 by Banque de France may be an example. Six of these members were representing the finance, industry, politics, science and journalism. The restriction of the democratic responsibility of the central bank may cause certain problems. The authorities of the central bank, which are well reflecting the social needs, are not eager to agree that they should be more conservative than society. This attitude of authorities allows the responsible monetary policy ${ }^{38}$.

Democratic independence is a mechanism ensuring a democratic functioning of the central bank. It is also a trigger to carry out the targets which are compatible with the lawfully given mandate ${ }^{39}$.

The concept of democratic responsibility appeared due to rising independence of the central banks. Today it is difficult to depict a model of responsibility of the central bank because of a high variety of institutional solutions in different countries.

\footnotetext{
36 Art. 227, Konstytucja RP.

37 R. Huterski, Niezależność..., op.cit., pp. 140-141.

38 Ibidem, p. 141.

39 Cf. M. Kowalak, Instytucjonalne..., op.cit., p. 240.
} 


\section{CONCLUSION}

The shape of functional institutions in a specific country has an influence on the results of economic policy. The institutions which operate in each country are linked together. Bad functioning of these institutions as a group affects the evaluation of others. In the same way we may perceive the functioning of the central bank of a country. The trust given to the central bank will be bound up with the trust to other institutions in the country. In the case of a country with a settled democracy as well as political stability, the central bank as an institution becomes more reliable and credible.

Faster evolution of the role of the central banks is what we may observe nowadays. It is fulfilled by the evolutionary and revolutionary changes taking place in the monetary system. With subordinate institutions the central banks become an equal partner of the government. The central banks affect the economy as a whole, especially by monetary policy. Nowadays, all over the Word there is a trend of strengthening the position of the central banks in the economic systems. It is also reflected by the European Union's recognition of the independence of the institutions that formed the European System of Central Banks ${ }^{40}$. Strengthening the independence of the central bank reinforces the democratic character of a country. It symbolizes another force in the country which along with the government may very effectively influence economic policy of a country. Most of the time though it is the central bank that cares more about economic effects in the long term, trying to counteract the action taken by politicians.

The independence of the central bank may provoke disputes between the government and the central bank from the economic point of view. Apart from a few serious experiences connected with disputes, it is rather unlikely for the independence of the central bank to be put in question ${ }^{41}$. If the independence of the central bank is strengthened it gives conditions

\footnotetext{
40 More about ESBC by W. Szymborski, Unia Europejska. Struktura - instytucjeprawo, Bydgoszcz 2005, pp. 186-188.

41 In 2009, there was a case when we faced a trial to limit the independence of the central bank; See T. Borkowski, Zamach na niezależność NBP, http://biznes.interia.pl/ news/zamach-na-niezaleznosc-nbp,1342459,,2 [21.07.2011]
} 
of cooperation between the government and the central bank. Such cooperation helps to make decisions optimum for the economy.

Maintaining the independence of the central bank allows:

- ceteris paribus taking steps to reduce inflation,

- increasing the credibility of monetary policy (e.g.: by allowing the central bank to concentrate on one target),

- restricting, different levels of inflation and increasing the effectiveness of deflation of the central bank policy,

- it promotes economic growth e.g.: restricting the interchange ability of inflation - economic growth in the long term ${ }^{42}$.

In the longer perspective, the independence of the central bank, as an institution functioning in the country, should be strengthened. It is connected with the consequent obeying the criteria which describs the independence.

Democratic responsibility of the central bank should be a completing part of its independence. This may happen if the democratic control devices are properly distributed and used, and do not contradict the assumption to independence.

\footnotetext{
42 M. Kowalak, Bank centralny od A do Z, Jakościowe aspekty polityki współczesnego banku centralnego, "Bank i Kredyt”, March 2006, p. 8.
} 